\title{
The technostress: Its influence in the learning environment related to the use of information technologies
}

\section{La tecnostress: Su influencia en el entorno de aprendizaje relacionado con el uso de las tecnologías de la información}

\author{
ORTIZ-SÁNCHEZ, Pedro Alfonso Guadalupe ${ }^{1} \dagger^{*}$, SÁNCHEZ-ITURBE, Patricia ${ }^{2}$, ORTIZ-Y OJEDA, \\ Pedro T. ${ }^{2}$ and BASAVE-TORRES, Rosy Ilda ${ }^{2}$
}

\author{
${ }^{I}$ Instituto Tecnológico de Mérida \\ ${ }^{2}$ Instituto Tecnológico de Tuxtla Gutiérrez, TecNM
}

ID $1^{\text {st }}$ Author: Pedro Alfonso Guadalupe, Ortiz-Sánchez / ORC ID: 0000-0002-2466-1837, Researcher ID Thomson: G5253-2019, CVU CONACYT ID: 803273 ID $1^{\text {st }}$ Coauthor: Patricia, Sánchez-Iturbe / ORC ID: 0000-0001-9245-3725, Researcher ID Thomson: G-6132-2019, Open
ID: 11667006

ID $2^{\text {do }}$ Coauthor: Pedro T., Ortiz-y Ojeda / ORC ID: 0000-0001-6153-4194, Researcher ID Thomson: G-6959-2019. CVU CONACYT ID: 205520

ID $3^{\text {er }}$ Coauthor: Rosy Ilda, Basave-Torres / ORC ID: 0000-0002-7305-3897, Researcher ID Thomson: G-5880-2019, CVU CONACYT ID: 720064

DOI: $10.35429 / J E D T .2019 .4 .3 .22 .28$

Received March 28, 2019; Accepted June 20, 2019

\begin{abstract}
This educational research is carried out to know and rate the level of technostress that the students of bachelor degree may have in order to analyze the presence of this factor of psychosocial risk and its relation to the degree of dropping out and failing that is currently presented. This is accomplished with the objective of the TecNM, of being an institution for the integral formation of competent professionals, and for the implementation of the necessary learning strategies for its achievement. A questionnaire (Cronbach's alpha: 0.913) was designed and administrated to students of 2 different programs, one of them with the obligatory use of ICT (Information and Communication Technologies), who during their training use ICT in almost all their subjects. The other was the control group composed of students who use ICT not that often. The applied survey tries to find out positive and negative aspects related to the use of technologies such as attitude, efficiency and anxiety. The initial results show little differences between the two programs, high level of addiction and anxiety which could be a matter to be considered within options to improve or design alternatives to avoid its development, so that it doesn't influence the raising of indicated rates.
\end{abstract}

Techno stress, Strategies, Learning, ICT

\begin{abstract}
Resumen
Esta investigación educativa se lleva a cabo para conocer y calificar el nivel de estrés técnico que pueden tener los estudiantes de licenciatura para analizar la presencia de este factor de riesgo psicosocial y su relación con el grado de abandono y fracaso que se presenta actualmente. Esto se logra con el objetivo de TecNM, de ser una institución para la formación integral de profesionales competentes y para la implementación de las estrategias de aprendizaje necesarias para su logro. Se diseñó y administró un cuestionario (alfa de Cronbach: 0.913) a estudiantes de 2 programas diferentes, uno de ellos con el uso obligatorio de las TIC (Tecnologías de la Información y la Comunicación), que durante su formación utilizan las TIC en casi todas sus asignaturas. El otro era el grupo de control compuesto por estudiantes que usan las TIC con poca frecuencia. La encuesta aplicada intenta descubrir aspectos positivos y negativos relacionados con el uso de tecnologías como la actitud, la eficiencia y la ansiedad. Los resultados iniciales muestran pequeñas diferencias entre los dos programas, alto nivel de adicción y ansiedad, lo cual podría ser un tema a considerar dentro de las opciones para mejorar o diseñar alternativas para evitar su desarrollo, de modo que no influya en el aumento de las tasas indicadas.
\end{abstract}

Estrés tecnológico, Estrategias, Aprendizaje, TIC

Citation: ORTIZ-SÁNCHEZ, Pedro Alfonso Guadalupe, SÁNCHEZ-ITURBE, Patricia, ORTIZ-Y OJEDA, Pedro T. and BASAVE-TORRES, Rosy Ilda. The technostress: Its influence in the learning environment related to the use of information technologies. Journal-Economic Development Technological Chance and Growth. 2019. 3-4: 22-28

\footnotetext{
* Correspondence to Author (email: portiz130@gmail.com)

$\dagger$ Researcher contributing first author.
} 


\section{Introduction}

The use of technology can be convenient because it allows to be constantly connected and communicate at all levels, the incommunication can produce a sense of anxiety that attacks the individual, which makes him intensely desire to be reconnected (1)

The presence of new pathologies derived from the inadequate use of new technologies manifests itself in debates, questions and concerns in all educational and social environments. Regardless of accepting its great advantages such as the ability of global communication, training and belonging to groups, public or social reporting, instant communication, the possibility of buying or selling, etc., and its own disadvantages such as identity theft, fraud, depersonalization, false information traffic, waste of time and productivity, feeling of helplessness, intellectual exhaustion in its absence (3) and cyberbullying among others, and despite considering that virtual technologies represent innovative strategies for learning and teaching, it is recognized that students of the new generations, to incorporate these practices and customs are developing some personality disorders such as anxiety, addiction and stress. It is a fact that the problems mentioned above, influence student performance and academic and social development (2).

Technostress is a concept coined by the American psychiatrist Craig Broad in 1984, and later by Rosen y Well, in 1997(4), who defined it as "Any negative impact (direct or indirect) of technology in the aptitudes, thoughts, behaviors o physiology of the human body" it is a social phenomenon that has been little studied and that emphasizes a current issue for the society and educational institutions, which are expected to propose alternative to reflect on the damage caused by the excessive and uncontrolled use of technology to avoid its development, to prevent its occurrence and the affectations that may be generated. Some authors consider that the problem is not the new technologies themselves but its pathologic use that can create addiction and anxiety(2), Salanova et al. (2003) focuses on the need of understanding the importance of its correct use as well as the prevention of its addiction in family and academic contexts due ICT allow the agile transmission of knowledge and information.
And also involves the possibility of exchanging information, data, notes, readings, etc., among physically distant people, and that in turn represent important and useful academic and social advances. There are few studies are related to the knowledge of technostress in students, some research has been applied to university professors, Bondac, Ilie and Sinisi (2019) point that the use of technologies increases stress among teachers; Conducting a comparative study of the use of Tic's between professors of public and private universities, Tapasco and Giraldo (2017) showed differences in their preference between both groups, such as a high level of stress between those who do use them as a teaching support.

Previously and as a part of the research project, they have been evaluated some motivational aspects related with the risk of generating failing, dropping out and school lag (Ortiz-Sánchez et al, 2018). One of these aspects identified as a possible factor of risk, is technostress which, for the anxious or negative response that can generate, and its impact with the academic development, is an interesting aspect to analyze and propose solution alternatives to those scholar issues. As a result of this research there was a close approach to the concept of technostress perceived by Engineering in Computer Systems and Engineering in Biochemistry students (TecNM), in order to find if they have experienced it, and if this one may represent a cause of dropping out and school lag, which it was an issue in both majors.

\section{Methodology}

Through a stratified random sampling process, 108 out of a total of 363 students from the two majors were selected: Computer Systems Engineering (CSE) and Engineering in Biochemistry (EB), from the first, second, eighth and ninth semesters enrolled in the program during the term Aug-Dec 2018. The age range of the students of the early semesters are from 19 to 20 years, the senior students are between 23 and 24 years of age; in BCE program $47 \%$ and in CSE $28 \%$ of students are women, the difference to $100 \%$ are male student who are students of undergraduate level in Engineering of the Technological Institute of Tuxtla Gutiérrez (TecNM). 
Although 9 different programs of Engineering are taught at the Institution, this time the students of these two majors were chosen because they were the people of interest for the research. Surveys were applied to groups of students of very different majors in the use of technology, the application was made in the first semesters because they are the ones with the highest propensity to fail (approximately 22\%), lag and drop out (9\%) according to data from the Department of School Control of the Technological Institute of Tuxtla Gutiérrez, TecNM (2017). Likewise, the answers of 8th and 9th semesters students were taken into consideration due they are the young people who are about to graduate from the bachelor's degree and represent a comparison group to estimate as objective to know if they manifest a greater or lesser degree of technostress.

For the sampling, it was taken in to consideration the total population of enrolled students in the indicated semesters and term. In the absence of previous proposals referred to the evaluation of technostress in engineering students, the survey to be applied was prepared and validated with the support of teachers from the faculty in Educational Research of the TecNM. Initially a proposal of 60 questions was generated, which was later adapted through the personal assessment of professors from the Department of Computational Systems Engineering and Biochemical Engineering of ITM and ITTG (TecNM), who reviewed the wording and the topic of interest. 17 questions were eliminated, which in their opinion are not related or were repetitive, leaving the survey with a total of 43 questions.

Prior to the application of the survey, an explanation was given to the students of interest about the importance of the research, the knowledge on technostress, the meaning of the ICT and the Likert scale used in values from 1 to 5 (from less to more) to express the degree in which someone will or will not agree on the questions of different aspects related to performance, attitudinal responses and frequency of use of ICT. Through a preliminary test applied, the survey obtained a high degree of reliability (Cronbach's alpha equal to 0.913). The survey included topics related to frequency of use, conditions and attitudes to determine the activity and use of technostress, grouped into 3 dimensions:
The use of ICT, which could be conducive to A) Failing, B) Dropping out, and C) stress and school support. Later, the application of the survey it was determined the average values and various statistical responses. The comparison of means was made between students of the same semester, between students of the first and last semesters of the same bachelor's degree and also of the 2 different majors (SPSS), also a comparison analysis of the media was applied (ANOVA, F of Fisher). The quantitative evaluation in this research shows the prevalence and / or the manifestation of technostress and perceive some relation between the high degrees of failing, lag and / or the dropping out of the students.

\section{Results}

There are few studies conducted to measure the presence of stress among engineering students. Among these studies, says Castillo Pimienta et al. (2016) those applied to health careers. There are another studies in which has also been evaluated among workers and users of technology, applying specific scales to measure anxieties and attitudes towards technology (5), or in university teachers (Tapasco and Giraldo, 2017)

According to the established objectives, the answers to know within the 3 dimensions indicated in the methodology were evaluated, the average values obtained, if there was or no difference between the means inter and intra groups of the students that use in a greater or lesser way ICT in their school performance using a Likert-type scale that oscillates between 0 and 5. Thus, high ratings in these dimensions are considered techno stress indicators.

\section{Analysis of the general answers of all students (CSE vs EB)}

In the data analysis made using the general sample of students, the tendency of the answers is observed in Graph 1. The students coincided to respond with certain similarity: engineering Computational Systems engineering and engineering in biochemistry, answered the questions in the scales given in a similar way though, as can be appreciated, there are significant differences in the averages of some answers. 
In $11.63 \%$ of the questions: the A4 ("I despair if I do not have access to the Internet", A5 ("I get desperate when someone does not answer me quickly"), B2 ("The frequency of the use of ICT generates great stress"), C3 ("I find it difficult to relax after a day of work using ICT") and C10 (Working with ICT makes me feel uncomfortable, irritable and impatient). There was significant statistical difference of means, the answers did not exceed the value of 3 ("It is indifferent to me".) In 3 questions, which represent $9.3 \%$ of the survey, in 3 of them, the C13 ("I have several windows open in the browser to perform multiple tasks at the same time"), C14 "(Upon awakening, I review the time and notifications on my cell phone") and C15 ("I despair if I do not have access to the Internet"), with an approximate average of 4 , a certain degree of technostress is registered.

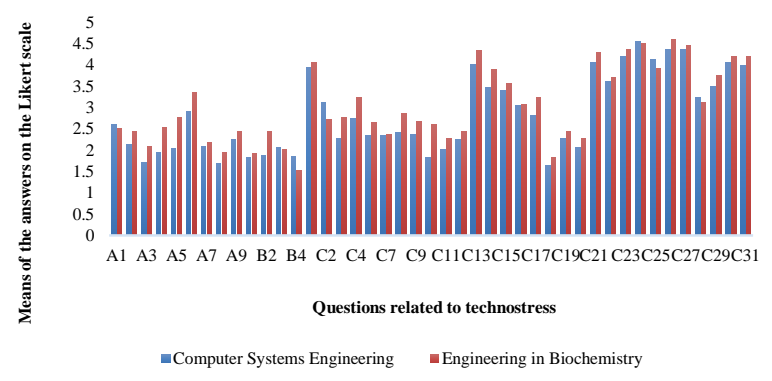

Graph 1 Means of Computer Systems Engineering and Engineering in Biochemistry

Source: Own Elaboration

\section{Analysis of the answers of the first semesters (CSE vs EB)}

When comparing the answers of the first semesters of both bachelor's degree, in most of them are observed higher averages in the students of Engineering in Biochemistry (see Graph 2), denoting values close to 3 ("I am indifferent") and in some cases higher than 4 ( Fairly agree) especially in the questions of group C. In the graph it is shown that there is greater degree of stress in EB students. In analysis by ANOVA, it can be differentiated significantly in $13.96 \%$ of the answers: A6 ("I feel very tired after using the computer or the device for several hours that I do not want to continue with my activities"), B2 ("The frequency of use of ICT generates great stress for me), C12 ("Whenever I can avoid the use of ICT"), C14 ("When I wake up I check the time and notifications on my cell phone"), C17 ("When I use my device, I can spend hours without realizing it") and C26 ("We sent homework by social networks"), perceiving differences in personality, formation and vocation.
Just in the means of communication of questions C14 and C26 show values close to 4 (Fairly agree).

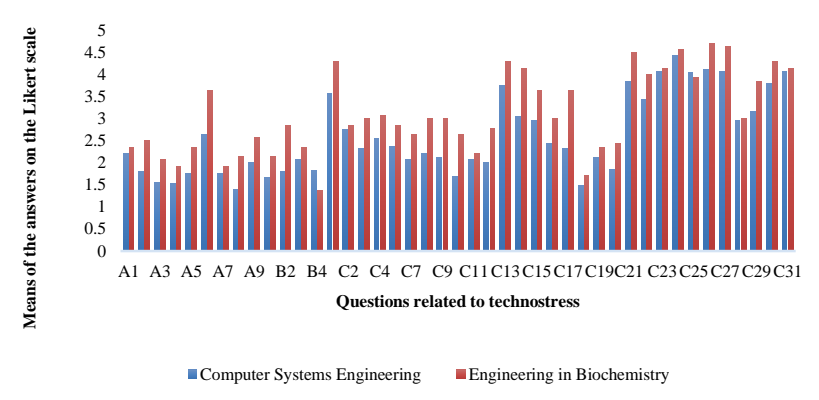

Graph 2 Means of first semesters in Computing Systems Engineering and Engineering in Biochemistry Source: Own Elaboration

\section{Analysis of the responses of the intermediate semesters (CSE vs EB)}

Similarly, when comparing the answers of the students from both groups (see Graph 3), intermediate semesters are found in EB students who normally respond with higher scores, notably in 17 questions (C12 to $\mathrm{C} 16, \mathrm{C} 20$ to $\mathrm{C} 27$ and $\mathrm{C} 29$ to C31) close to $40 \%$, the means have values higher than 4 . There is also a significant difference between the groups in the questions B2 ("The frequency in the use of ICT generates me higher stress"), C10 ("Working with ICT I feel uncomfortable, irritable and impatient"), C12 ("Whenever I can I avoid to use ICT"), and C17 ("When I am in my device, I spend hours without realizing it") of which only the last one exceeds the value of 3.5 , manifesting between groups, a different way of facing stress.

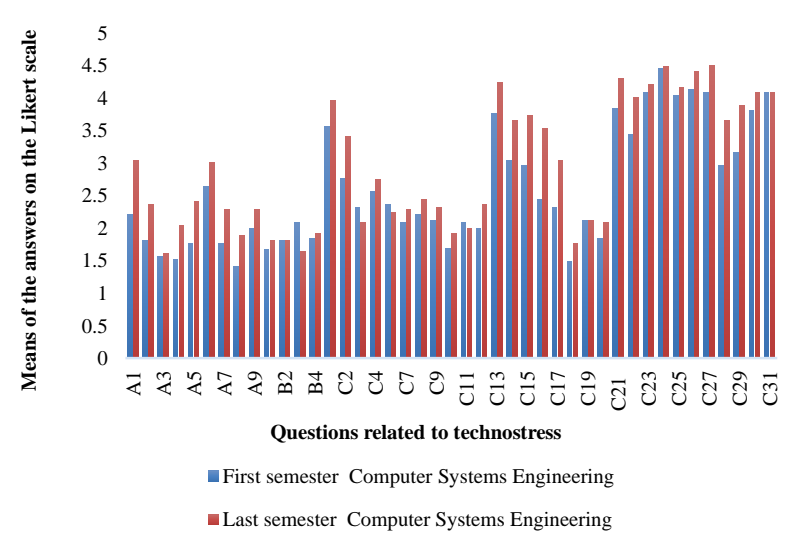

Graph 3 Means of First and Last semester of Computer Systems Engineering

Source: Own Elaboration 


\section{Analysis of the responses of the first and last semester of CSE}

The answers given between students of first and eighth semester of Computer Systems Engineering follow the trend of lower values in the answers to categories $\mathrm{A}$ and $\mathrm{B}$ and higher in items C (see Graph 4), in this comparison only in the question $\mathrm{C} 16$ ("There are so many things to see on the Internet that I spend hours and I do not get bored") there was a significant difference, with all the answers being much higher than the average number of students next to graduate.

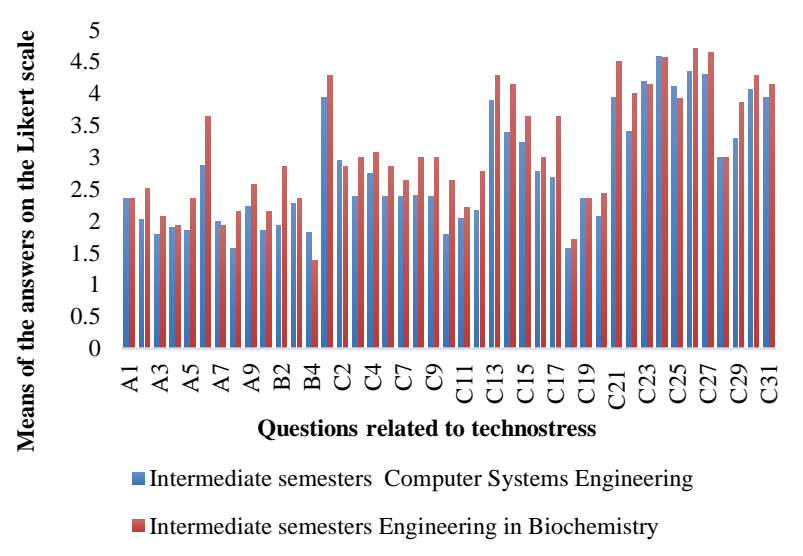

Graph 4 Means of intermediate semesters of Computer Systems Engineering and Engineering in Biochemistry Source: Own Elaboration

\section{Analysis of the answers of the first and last semester of EB}

In this comparison, the general tendency to show higher values in the scale in the students of the last semester and also in the $\mathrm{C}$ responses continues (see Graph 5). The comparison of means in this group does not show any significant difference. In the responses from $\mathrm{C} 21$ to $\mathrm{C} 26$ as well as from $\mathrm{C} 29$ to $\mathrm{C} 31$, all show means higher than 4 , some have averages very close to 5 (representing approximately $21 \%$ ).

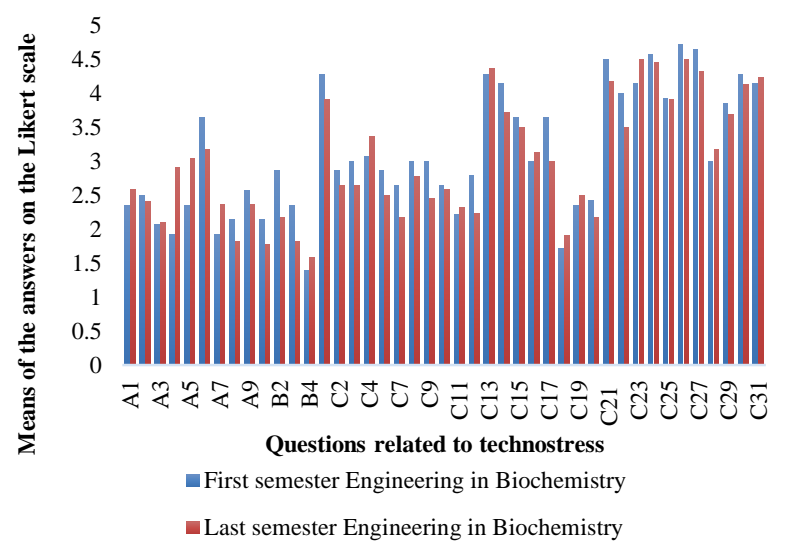

Graph 5 Means of first and last semesters of Computer Systems Engineering and Engineering in Biochemistry Source: Own Elaboration

Something notorious is that in all the different comparisons made inter and intra groups, the sample of students answered question C1 ("I would not like to have technostress when practicing my profession"), always with average values between 4 and 5 , between fairly and totally agree. In the comparisons of responses from the first semesters to question C18 ("When I finally leave the device I feel very anxious or nervous and sometimes even angry") obtained the lowest average 1.6.

In the comparison in the question A3 ("I used to delay in the accomplishment of academic tasks due to the need to update my social networks in a short period of time"), A4 ("I have wanted to damage a technological device due to the desperation of not obtaining things on the computer or device"), A8 ("I get bad after using the computer or mobile for many hours") B1 ("The stress of using ICT could lead to my dropping out"), C12 ("Whenever I can I avoid the use ICT") and C10 ("Working with ICT makes me feel uncomfortable, irritable and impatient"), all the averages were values between 1.5 and 2 , representing $16.37 \%$, in general, the overall results of the application of this survey indicate the variable presence of technostress among students.

As indicated in the introduction, the irregular use of Information and Communication Technologies can generate different degrees of technostress, academic demands are varied, are present in students and are associated with certain psychological costs perceived as anxiety when they do not have access to the Internet. 
The stress perceived by the frequency of the use of ICT, manifested by irritability and even impatience and anger. The students uniformly declare in all the comparisons made that the techno stress is not a cause of their dropping out. Both the initial, intermediate and final semesters, accept that they would not be able to leave their studies under this type of pressure. It is observed that the CSE students from the first semesters have a higher degree of technostress compared to those of EB, but at the end of the bachelor degree, this trend is reversed: EB students showed higher values in their answers.

The foregoing may indicate some ignorance of what the challenges that could be presented throughout their academic preparation. It also shows some degree of adaptation due to the high use of ICT that the CSE students require for their training. However, it cannot be ignored that the ignorance of the structure of the educational program, and the lack of information of the demands of the academic environment, are part of stress factors that can negatively influence the student. Even more, than the quality of teachers as a predictor of the perception of stress (Nerdrum et al., 2009). Undoubtedly, the presence of stress is a factor of vulnerability among students, in addition, some authors (Ortega Dias et al, 2017; Kember and Leung, 2006) agree that there is a certain correlation between the perception of stress and the use of superficial approaches of learning, even associating with slow learning and with errors.

Due to the above, it is important to consider techno as a stressful factor that, although it does not seem to favor dropping out of school, there is the possibility of explaining the high rate of lag and failing, and even to suggest alternatives for proper management, such as the reduction of the academic load through a review and curricular planning of the courses, extracurricular courses related to the learning of resilience and relaxation (FrancosCabreros, 2015), in order to achieve a personal adaptation to the use of ICT or even provide technical support through training courses for the correct and proper use of different programs (software) of their interest.

\section{Conclusions}

The knowledge of the technostress was novel and interesting in our institution, since many teachers and even students did not know the term and its meaning, nevertheless and according to different authors, it must be taken into account as a factor from which psychological pathologies could be derived, social and academic and therefore avoid it or look for alternatives to reduce it.

The students who represented the sample of this study despite being of two bachelor's degree with very different application approaches, responded in a similar way. They indicated in their answers that the aspects related to the use of ICT and failing and dropping out are the least stressful, that is to say that they are not an immediate cause of a high level of technostress, but they state that they do require, that is, they need use of computers, internet, cell phones, etc. to be able to establish their social networks that allow them to communicate, work as a team and properly develop their tasks, thus, the questions "Without the ICT I could not do my academic work" and "When I use ICT for my classes or activities everything it is much better than not using them" were the ones that in all cases got the highest rated answers, with means close to 5 (totally agree).

Also, in general, students present higher levels of technostress at the end of their studies. This is an initial investigation, so it is suggested to continue investigating these levels of stress shown by students of the last semesters and conduct a study to determine if there are greater long-term consequences, when they are developing their professions. On the other hand, it is suggested to conduct research that allows to relate the variables studied here with others, such as academic benefit and satisfaction with what they are studying, despite these stressors.

It is to be considered that the level of technostress is still low among our students, although according to its definition it prevails and depends on various factors such as its ability to adapt to avoid damage due to the extensive use of ICT. 


\section{References}

Bondac, G.T., Ilie, O.-M., \& Sinisi, C.I. (2019). The Stress Generated by the Introduction of NICT in the Educational Environment. In M. Negreponti Delivanis (ed.), International Conference "Global interferences of knowledge society», November 16-17th, 2018, Targoviste, Romania (pp. 10-16). Iasi, Romania: LUMEN Proceedings.

https://doi.org/10.18662/lumproc.119

Castillo Pimienta C., Chacón De laCruz T., y Diaz-Véliz G. (2016).Ansiedad y fuentes de estrés académico en estudiantes de carreras de la salud Inv Ed Med. 5(20):230-237.

Francos Cabreros V.(2015) Técnicas de relajación en el aula: propuesta teórica para desarrollar el autocontrol. Tesis de Grado, Facultad de Educación de Soria, Universidad de Valladolid, España.

Kember, D. y Leung, D. Y. P. (2006). Characterising a teaching and learning environment conducive to making demands onstudents while not making their workload excessive. Studies in Higher Education, 31, 185$--198$.

Nerdrum, P., Rustøen, T. y Rønnestad, M. H. (2009). Psychological distress among nursing, physiotherapy and occupational therapy students: A longitudinal and predictive study. Scandinavian Jour-nal of Educational Research, 53, 363---378. http://dx.doi.org/10.1080/00313830903043133

Ortega Díaz C., Hernández Pérez A. y Ponce Millas O. M. (2017) Causas que propician el aprendizaje superficial: de la reflexión a la práctica docente XV Congreso Nacional de Investigación Educativa, San Luis Potosí S. L. P.

Ortiz-Sánchez Pedro Alfonso Guadal, Sánchez Iturbe, P., Ortiz y Ojeda P. y Hernández Garduza S. (2018). La motivación como elemento compensatorio para el desarrollo de estrategias didácticas en programas de licenciatura por competencias. Revista Ciencias de la Educación, vol. 2 No. 6, pp. 1-7.
Salanova M, Llorens S., Cifre E., Martínez I. M., Schaufeli W. B. (2003), Eficacia colectiva percibida, bienestar subjetivo y desempeño de tareas entre grupos de trabajo electrónico: un estudio experimental. Investigación de grupos pequeños. Vol. 34 No. 1, pp. 43-73.

Tapasco Omar A, y Jaime A.Giraldo (2017). Estudio comparativo sobre la percepción y el uso de las TIC en docentes de universidades públicas y privadas. Formación universitaria , 10 (2),0312. https://dx.doi.org/10 .4067/S0718-50062017000200002

Quintero J, Munévar RA, Munévar FI. Nuevas tecnologías, nuevas enfermedades en los entornos educativos. Hacia promoc. salud. 2015; 20(2): 13-26. DOI: 10.17151/hpsal.2015.20.2.2

(1)https://psicologiaymente.com/clinica/nomofo bia-adiccion-telefono-movil, Nomofobia: la creciente adicción al teléfono móvil por Juan Armando corbin .consultado el 1 de febrero de 2019.

(2)https://psicologiaymente.com/clinica/tecnoes tres, Tecnoestrés: la nueva psicopatología de la "era digital"por Jonathan García-Allen. Consultado el 10 de Noviembre de2018.

(3)https://www.lifeder.com/sindrome-deburnout-combatirlo-en-7-pasos. Síndrome de Burnout o del Quemado: 7 Pasos para Combatirlo por Alberto Rubio Marín. Consultado el 3 de Mayo de 2019.

(4)http://www.insht.es/InshtWeb/Contenidos/D ocumentacion/FichasTecnicas/NTP/Ficheros/70 1a750/ntp_730.pdf

(5)https://www.insst.es/InshtWeb/Contenidos/D ocumentacion/FichasTecnicas/NTP/Ficheros/70 1a750/ntp_730.pdf 